\title{
Particleboard Manufactured from Tauari (Couratari oblongifolia) Wood Waste Using Castor Oil Based Polyurethane Resin
}

\author{
Washington Luis França Santos ${ }^{a, b}$, Antônio Jorge Parga da Silva , \\ Aluísio A. Cabral ${ }^{a, d}$, José Manuel Rivas Mercury ${ }^{a, e * *}$ \\ ${ }^{a}$ Postgraduate Program in Materials Engineering - PPGEM, Federal Institute of Education, \\ Science and Technology of Maranhão - IFMA, Av. Getúlio Vargas, 04, Monte Castelo, \\ CEP 65030-005, São Luis, MA, Brazil \\ ${ }^{b}$ Department of Design - DDE, Federal Institute of Education, \\ Science and Technology of Maranhão - IFMA, São Luis, MA, Brazil \\ ${ }^{c}$ Department of Civil Construction - DCC, Federal Institute of Education, \\ Science and Technology of Maranhão - IFMA, São Luis, MA, Brazil \\ ${ }^{d}$ Department of Physics - DEFIS, Federal Institute of Education, \\ Science and Technology of Maranhão - IFMA, São Luis, MA, Brazil \\ ${ }^{e}$ Department of Chemistry - DAQ, Federal Institute of Education, \\ Science and Technology of Maranhão - IFMA, São Luis, MA, Brazil
}

Received: July, 23 2013; Revised: January 16, 2014

\begin{abstract}
Several wood species from the Amazon region are used in the manufacture of furniture, which leaves behind large amounts of waste (slabs, sawdust, sanding dust and bark), thus causing serious environmental impacts. An interesting alternative for the use of these wastes is the manufacture of particleboards. However, few studies have focused on the behavior of Amazonian tree species and the wastes resulting from production with this type of material. This paper discusses the potential use of Tauari (Couratari oblongifolia) wood waste as a raw material for the production of particleboards, using castor oil-based bi-component polyurethane adhesive. Experimental boards were prepared with dry wood particles and a castor-oil polyurethane adhesive content of $16 \%$. The boards, whose nominal density was $1000 \mathrm{~kg} \cdot \mathrm{m}^{-3}$, were subjected to uniaxial compression $(5 \mathrm{MPa})$ at 90,110 and $130^{\circ} \mathrm{C}$ for ten minutes. The particleboards were characterized by performing the following tests: Apparent density $\left(\mathrm{D}_{\mathrm{AP}}\right)$, Moisture (M), Water Absorption (WA), Thickness Swelling (TS), Static bending strength: MOR (Modulus of rupture) and MOE (Modulus of elasticity), Perpendicular Tensile Strength (IB - internal bonding) and Screw Pullout (SP), according to the Brazilian NBR 14.810:2006 standard. The results indicate that, regardless of the processing temperature, the average density of Tauari particleboard is 930 to $941 \mathrm{~kg} \cdot \mathrm{m}^{-3}$, with higher IB and TS than those specified by the NBR 14810-2 and ANSI A208.1 standards, enabling this product to be classified as high-density particleboard suitable for industrial and commercial use.
\end{abstract}

Keywords: Tauari particleboard, castor oil polyurethane, physicomechanical properties

\section{Introduction}

Community forest management is a sustainable practice that involves the rational exploitation of forest resources for the preservation of forests and ecosystems. The use of management as a tool for conservation has increased considerably in recent years in Amazonia ${ }^{1}$. This practice currently focuses on the reduction of logging, which is encouraged by NGOs and local governments through incentives and subsidies ${ }^{1}$. Selective logging and slash-andburn deforestation cause drastic environmental impacts, particularly the reduction of exploited species, affecting the natural regeneration of trees ${ }^{2,3}$.

An alternative that can contribute to reduce wasteful deforestation is to use the wastes (leaves, branches, twigs,

*e-mail: rivascefetma@gmail.com chips, bark, sawdust or wood shavings) for the manufacture of composite materials called particleboards ${ }^{4-7}$ as a way to reduce costs and increase revenue in rural settlements ${ }^{8}$, since these wastes represent $50.7 \%$ of all log production 9 .

Tauari (Couratari oblongifolia) is a tree belonging to the family Lecythidaceae, which occurs throughout Amazonia, mainly in the states of Pará, Amazonas, Acre, Rondônia and Maranhão, and in neighboring countries such as French Guiana, Suriname, Peru and Venezuela ${ }^{10}$. Tauari wood has the following characteristics: moderately heavy $\left(620 \mathrm{~kg} \cdot \mathrm{m}^{-3}\right)$ and easy to cut; heartwood and sapwood of undifferentiated color, pinkish tending to straw white; medium texture; straight grain; slightly glossy and smooth surface; and unnoticeable smell and taste ${ }^{11}$. However, records about the 
use of this wood in the manufacture of particleboard are almost nonexistent in the literature.

According to Maloney ${ }^{12}$, the processing temperature is one of the most significant properties in the manufacture of agglomerated particleboards. Moreover, the following factors must be considered: the wood species, particles size and geometry, compaction pressure, type of resin and/or adhesive, and their mixing time.

The literature contains several studies on the manufacture of particleboards using particles or fibers from different lignocellulosic sources and synthetic binders or adhesives ${ }^{7,13-20}$ to bond the particles, often by applying heat ${ }^{21}$. Castor oil-based bi-component polyurethane adhesive ${ }^{22}$ has been widely used because it is renewable, biodegradable and has a low degree of toxicity ${ }^{23-25}$.

Dias and $\mathrm{Lahr}^{26}$ used castor oil-based polyurethane resin (COPR) as an alternative adhesive for the production of plywood panels with layers of Eucalyptus grandis wood species. The physical and mechanical tests indicated that the properties of plywood manufactured with COPR at low temperature $\left(60^{\circ} \mathrm{C}\right)$ were superior to those of commercial panels fabricated with Brazilian tropical woods, using traditional adhesives at low temperature.

Campos et al. ${ }^{27}$, who produced and characterized medium density fiberboard (MDF) from alternative raw materials (Eucalyptus fibers) and COPR, showed that MDF produced with eucalyptus fiber and castor-oil-based polyurethane resin presents very satisfactory results when compared with standard Euro Class MDF boards.

Iwakiri et al. ${ }^{28}$ evaluated the influence of density on the mechanical properties of particleboards with nominal densities of $0.60,0.70,0.80$ and $0.90 \mathrm{~g} / \mathrm{cm}^{3}$, using Pinus spp particles collected from a particleboard manufacturing plant and urea-formaldehyde resin. Their results indicated a correlation between particleboard density and mechanical properties, and demonstrated the possibility of predicting these properties based on board density. Based on these results, they concluded that particleboards can be manufactured with an average density above $0.80 \mathrm{~g} / \mathrm{cm}^{3}$ for specific applications that require high mechanical strength.

In another study, Fiorelli et al. ${ }^{29}$ investigated the production and properties of particleboards made of sugarcane bagasse and castor oil mono-component and bi-component resin. The characterized materials, which presented an average density of $0.93 \mathrm{~g} \cdot \mathrm{cm}^{-3}$, can be classified as high density material recommended for industrial use, showing that castor oil based resin was efficient as a polymer matrix for the production of composite boards made of sugarcane bagasse.

Paes et al. ${ }^{30}$ evaluated the combined effect of pressure (2.0, 3.0, and 3.5 MPa) and temperature $\left(50,60,90^{\circ} \mathrm{C}\right)$ applied to Pinus elliottii wood and COPR particleboard on the response variables: $\mathrm{D}_{\mathrm{AP}}$, TS and WA (0-2h, 2-24, 0-24h), MOR, SP and IB. They concluded that the combination of $3.0 \mathrm{MPa}$ and $90^{\circ} \mathrm{C}$ and of $3.5 \mathrm{MPa}$ and $60^{\circ} \mathrm{C}$ produced the best results, and that the temperature at which pressure is applied is the most important variable in particleboard quality.

The use of coconut fiber as raw material to produce particleboards, using COPR adhesive and urea-formaldehyde (UF) with two different densities $\left(0.8 \mathrm{~g} / \mathrm{cm}^{3}\right.$ and $\left.1.0 \mathrm{~g} / \mathrm{cm}^{3}\right)$, was investigated by Fiorelli et al. ${ }^{31}$ Their results indicated a decrease in TS and an increase in MOR of coconut fiber panels with polyurethane resin when compared to those of coconut fiber panels manufactured with urea-formaldehyde resin. These observations were explained based on scanning electron microscopy (SEM) micrographs, which indicated that castor oil-based polyurethane adhesive occupies the gaps between the particles, thus contributing to improve the physical and mechanical properties of the panels.

Iwakiri et al. ${ }^{32}$ used sawmill waste from nine tropical wood species from Amazonia, including Couratari oblongifolia (Tauari), to evaluate the quality of particleboards using urea-formaldehyde resin as adhesive (8\% of solid in oven-dried wood particles), and applying a pressure of 40 $\mathrm{kgf} / \mathrm{cm}^{2}$, a temperature of $160^{\circ} \mathrm{C}$ and a pressing time of $8 \mathrm{~min}$. The characterization tests indicated that the best physical and mechanical properties were achieved with Ecclinusa guianensis (Caucho) wastes.

Bertolini et al..$^{33}$ demonstrated that high density wood particles from urban tree pruning, including the bark, can be used to produce medium density particleboards (MDP) using COPR (prepolymer and polyol bi-component) at a ratio of $16 \%$ (based on wood mass).

Silva et al. ${ }^{34}$ examined the behavior of boards made of castor oil-based polyurethane resin with coconut and sisal as plain weaves, using unidirectional short fibers (10 $\mathrm{mm}$ of length) and unidirectional long fibers. Their results revealed that the properties of sisal were superior to those of coconut fibers and that increasing the volume fraction of fiber improved the tensile strength, stiffness and WA of the boards but decreased their flexural strength.

Silva et al. ${ }^{35}$ investigated the physical properties of particleboards manufactured with castor oil bi-component polyurethane resins and Cambará, Canelinha and Cedrinho wood fiber, using a $2^{2}$ full factorial design. The panels were produced with a particle moisture content of $5 \%$, nominal density of $0.80 \mathrm{~g} / \mathrm{cm}^{3}$, resin content of $15 \%$, pressure cycle of $10 \mathrm{~min}$, and a pressure of $5 \mathrm{MPa}$ applied at $100^{\circ} \mathrm{C}$. The resulting materials, which showed better mechanical and physical properties than those stipulated by the Brazilian NBR 14810:2002 standard, can be classified as high density particleboards.

Particleboards from leucena (Leucaena leucocephala) wood particles and COPR were also investigated by Silva et al. ${ }^{36}$. The particleboards were manufactured by hotpressing under $4 \mathrm{MPa}$ and $90^{\circ} \mathrm{C}$, using wood particles with a moisture content of $5 \%$ and $10 \%$ of mono-component and bi-component COPR. The bi-component COPR improved the physical properties (MOR and density) when compared to those recommended by the standard.

In this paper, we report on a study of the feasibility of producing particleboard made from Tauari wood waste agglomerated with castor oil-based polyurethane resin, and the influence of the processing temperature on the particleboard's physical and mechanical properties.

\section{Material and Methods}

\subsection{Material}

Tauari (Couratari oblongifolia) wastes in the form of chips and flakes supplied by the furniture industry of the municipality of João Lisboa (Maranhão, Brazil) were 
received in a laboratory and dried to a constant moisture content of 5\% (dry basis). The wood wastes were milled in a vertical milling machine with fixed and movable blades (MARCONI model MA 680) to homogenize the sample. After milling, the particles were sifted through 14-18 mesh sieves, and the material retained in the 18 mesh sieve (1 $\mathrm{mm}-\mathrm{ABNT}$ ) was used to fabricate the particleboards.

The wood particles were agglomerated with bicomponent castor oil-based polyurethane resin (COPR) with a density of 0.9 to $1.2 \mathrm{~g} / \mathrm{cm}^{3}$, manufactured by KEHL Indústria and Comércio, São Carlos, SP, Brazil, containing $0.1 \%$ of free formaldehyde after $24 \mathrm{~h}$.

\subsection{Preparation of the particleboards}

The particleboards were manufactured with $16 \%$ of COPR (bi-component) adhesive based on the wood mass, using a 1:2 ratio (one part of diisocyanate prepolymer and two parts of polyol). The resin was added to the particles and homogenized in a blender for five min. After homogenization, the mixture was placed in a $400 \mathrm{x} 400 \mathrm{x}$ $10 \mathrm{~mm}$ mold, compressed in a 50-ton hydraulic press and then hot pressed at $200^{\circ} \mathrm{C}$ (MARCONI model MA-098/50) for $10 \mathrm{~min}$. Press cycles were performed at 90, 110 and $130^{\circ} \mathrm{C}$, applying a pressure of $5 \mathrm{MPa}$ (pressure used in the industrial production of medium density panels), to reach a nominal density $1000 \mathrm{~kg} / \mathrm{m}^{3}$. Four particleboards were fabricated for each treatment at the Laboratory of Wood and Timber Structures (LaMEM) of the University of São Paulo (USP) at São Carlos, SP, Brazil. Table 1 describes the experimental conditions employed in the manufacture of the particleboards in the laboratory and the nomenclature used to identify each of the composites.

\subsection{Physical and mechanical characterization of the particleboards}

The particleboards were allowed to rest at ambient temperature for $48 \mathrm{~h}$. Twelve test specimens per treatment were then cut randomly from these particleboards for each physicomechanical test, as follows: i) Apparent Density $\left(\mathrm{D}_{\mathrm{AP}}\right)$ and Perpendicular Tensile Strength (IB) measurements

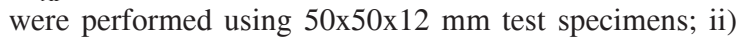
Thickness Swelling (TS) and Water Absorption (WA) tests were performed on $25 \times 25 \times 12 \mathrm{~mm}$ test specimens after $24 \mathrm{~h}$ of immersion in water; iii) Static bending tests (MOR and MOE) were carried out on 250x50x12 mm test specimens; and iv) the Screw Pullout (SP) test was performed with 250x50x24 mm test specimens. All the experiments were performed as recommended by the ABNT NBR 14810-3 standard $^{37}$.

\subsection{Statistical analysis}

In the analysis of the tests, the variables $\left(\mathrm{WA}, \mathrm{D}_{\mathrm{AP}}, \mathrm{M}\right.$, MOR, MOE, TS and SP) were expressed as mean values and were analyzed by the Shapiro-Wilk normality test, at a 5\% level of significance. An analysis of variance (oneway ANOVA) followed by a Tukey post-hoc test were used to detect differences between the three treatments of the Tauari particleboards in each variable assessed with normal distribution. The variables of SP, WA and MOR were compared by the Kruskal-Wallis test at a 5\% level of significance.

\section{Results and Discussion}

\subsection{Physical characterization of the particleboards}

The determination of physical and mechanical properties such as internal bond, static bending, screw pullout strength, density, water absorption and thickness swelling serve to indicate the quality of particleboards ${ }^{21}$. Figure 1 illustrates the densities of the particleboards.

As can be seen, the average densities of the particleboards at 90,110 and $130^{\circ} \mathrm{C}$ correspond to $930.3,932.2$ and $941.8 \mathrm{~kg} / \mathrm{m}^{3}$, respectively, with coefficients of variation not exceeding $4 \%$. The analysis of variance revealed no significant difference $(\mathrm{F}=0.4813, \mathrm{p}>0.05)$, indicating that the densities of the particleboards were statistically similar.

These values fall below the preestablished nominal density of $1000 \mathrm{~kg} / \mathrm{m}^{3}$, but are higher than those reported by Dias and $\mathrm{Lahr}^{26}$ and similar to those obtained by Fiorelli et al. ${ }^{31}$, Bertolini et al. ${ }^{33}$, Silva et al. ${ }^{35,36}$, and Sartori et al. ${ }^{38}$, who studied particleboards made of bi-

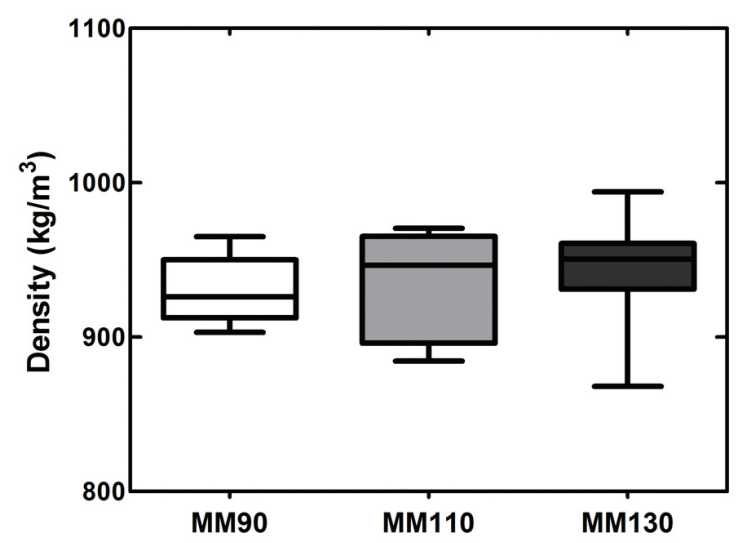

Figure 1. Average density of the Tauari particleboards.

Table 1. Treatment proposed for the manufacture of particleboards.

\begin{tabular}{ccccccc}
\hline Treatment & Temp. $\left({ }^{\circ} \mathbf{C}\right)$ & Code & Particle-boards & Pressure $(\mathbf{M P a})$ & Density $\left(\mathbf{k g} / \mathbf{m}^{3}\right)$ & Resin Binder \\
\hline 1 & 90 & MM90 & 04 & 5 & 1000 & CORP* \\
2 & 110 & MM110 & 04 & 5 & 1000 & CORP \\
3 & 130 & MM 130 & 04 & 5 & 1000 & CORP \\
\hline
\end{tabular}

\footnotetext{
*-CORP = Castor Oil-based Polyurethane Resin.
} 
component castor oil based polyurethane and several types of wood wastes. In every case, the compression ratio (CR) was about 1.5 , which is higher than the CR of 1.3 recommended by Moslemi ${ }^{39}$ and Maloney ${ }^{12}$.

The densities attained allow the particleboards to be classified as high-density, according to the ANSI A208.11999 standard $^{40}$. On the other hand, the difference between nominal and average density of particleboards has already been reported by other authors ${ }^{41,42}$, and has been attributed to the loss of raw material (wood particles and resin) during the manual mixing and pressing process.

The average moisture content of the particleboards varied from 5.51 to $8.29 \%$ (Figure 2), which falls within the range of 5 to $11 \%$ recommended by the NBR 14810-2 standard $^{43}$, and is lower than the minimum values of $8 \pm 2 \%$ for dry particles recommended by Deppe \& Erns, cited by Moslemi ${ }^{39}$.

The treatments at 110 and $130^{\circ} \mathrm{C}$ resulted in significantly lower moisture contents than in the particleboards treated at $90^{\circ} \mathrm{C}(\mathrm{F}=109.8, \mathrm{p}<0.001)$. This difference may be explained by the increase in compression temperature responsible for the evaporation of water adhered to the particle surfaces during processing, which also causes resin to cure with better densification of the particleboard ${ }^{44}$. The initial particle moisture content of 5\% did not affect the interaction with COPR and the homogeneity of the mixture, as was also observed by Silva et al. ${ }^{35}$.

Figure 3 illustrates the water absorption (WA) test results after $24 \mathrm{~h}$ of immersion of the particleboards in water. Note that the average WA of the particleboards compressed at $90^{\circ} \mathrm{C}$ exceeded $30 \%$. Increasing the processing temperature from $90^{\circ} \mathrm{C}$ to $110^{\circ} \mathrm{C}$ and $130^{\circ} \mathrm{C}$ led to a significant decrease in WA (from 22.49 to $19.87 \%$ ), representing a statistically significant difference $(\mathrm{F}=56.6, \mathrm{p}<0.001)$.

The difference in the average values of WA of the particleboards is ascribed to the decrease in resin viscosity. Increasing the processing temperature enhances the impregnation of the particles with resin, which reduces the thickness of the particleboards during compression, thereby increasing the degree of polymerization of the resin.

Low WA values are associated with high densities of particleboards and a high compressibility ratio (1.61:1). It should be noted that the Brazilian NBR 14810-2 standard $^{43}$ does not specify WA requirements for particleboard. The

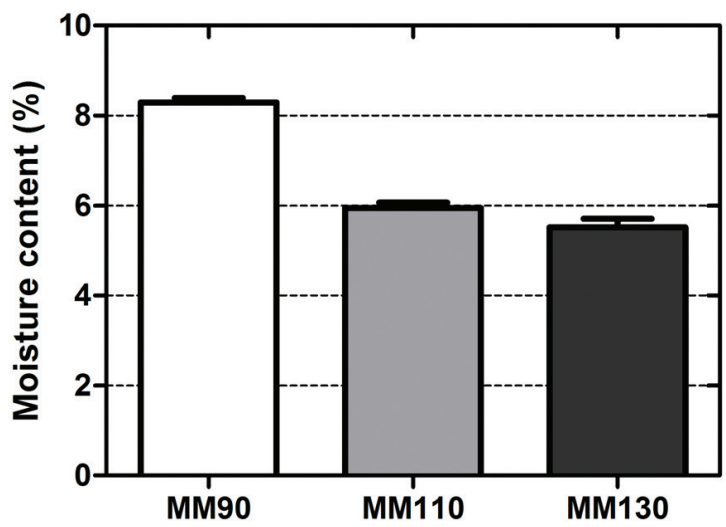

Figure 2. Variation in average moisture content of Tauari particleboards. average WA values of particleboards treated at $110^{\circ} \mathrm{C}$ and $130^{\circ} \mathrm{C}$ indicate that these temperatures are suitable for obtaining high density Tauari wood particleboards $\mathrm{s}^{40}$. These results are consistent with those obtained by Fiorelli et al. ${ }^{45}$ for particleboards made with COPR and sugarcane bagasse fiber and Pinus sp. and by Bertolini et al. ${ }^{46}$ and Iwakiri et al. ${ }^{32}$ for boards made of Tauri wood using ureia formaldehyde resin as adhesive.

Figure 4 depicts the thickness swelling (TS) values after $24 \mathrm{~h}$ of immersion in water. It should be kept in mind that the NBR 14810-2 standard $^{43}$ does not establish TS values for particleboard. However, this test allows one to observe more clearly the differences between the treatments, as well as the bonding and strength conditions of the particleboard particles after $24 \mathrm{~h}$ of immersion in water.

It can be observed (Figure 4) that the mean values of TS after 24 hours are lower than $15 \%$, which is consistent with the values obtained by Iwakiri et al. ${ }^{32}$ for Tauri wood using ureia formaldehyde resin. The particleboards treated at $130^{\circ} \mathrm{C}$ showed a significantly lower TS than those treated at 90 and $110^{\circ} \mathrm{C}(\mathrm{F}=6.47, \mathrm{P}<0.05)$, indicating that the compression temperature was a predominant variable in curing the adhesive. However, the mean TS values obtained for all the particleboards were lower than those reported by Sartori et al. ${ }^{38}$ and Fiorelli et al. ${ }^{29}$.

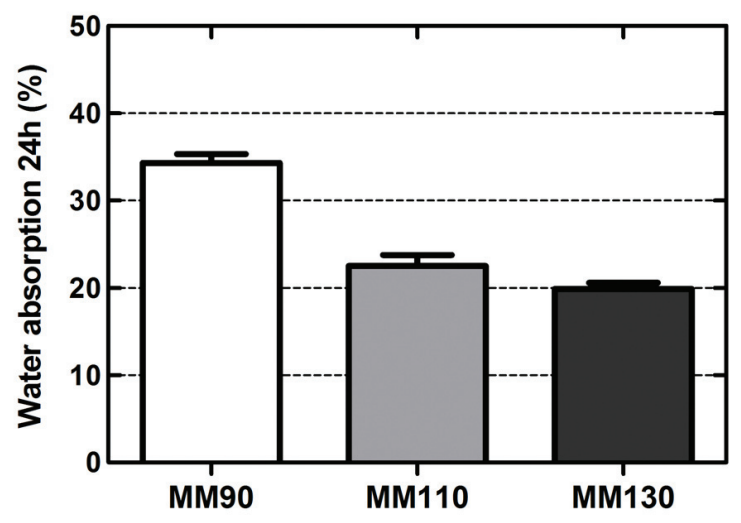

Figure 3. Water absorption of Tauari particleboards after $24 \mathrm{~h}$ of immersion.

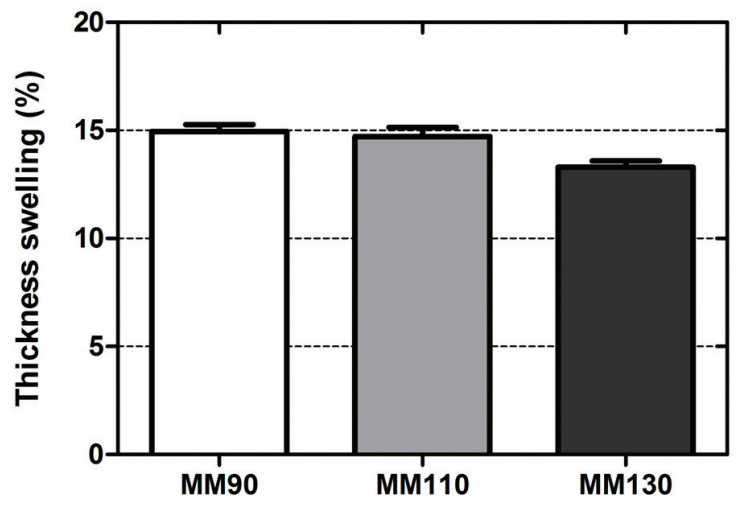

Figure 4. Thickness swelling of Tauari particleboards after $24 \mathrm{~h}$ of immersion. 
Table 2. Mean values of the mechanical properties of the particleboards.

\begin{tabular}{|c|c|c|c|c|}
\hline \multirow{2}{*}{ Treatment } & \multicolumn{4}{|c|}{ Mean \pm Standard error } \\
\hline & MOR (MPa) & MOE (MPa) & IB (MPa) & $\mathbf{S P}(\mathbf{N})$ \\
\hline MM90 & $15.85 \pm 0.25 \mathbf{a}$ & $1336.1 \pm 34.43 \mathbf{a}$ & $1.55 \pm 0.04 \mathbf{a}$ & $1668.9 \pm 19.29 \mathbf{a}$ \\
\hline MM110 & $16.02 \pm 0.47 \mathbf{a}$ & $2011.7 \pm 53.04 \mathbf{b}$ & $1.56 \pm 0.09 \mathbf{a}$ & $2098.8 \pm 236.3 \mathbf{a}$ \\
\hline MM130 & $19.58 \pm 0.57 \mathbf{b}$ & $2378.5 \pm 89.86 \mathbf{c}$ & $1.70 \pm 0.07 \mathbf{a}$ & $1719.1 \pm 16.67 \mathbf{b}$ \\
\hline
\end{tabular}

The same letters indicate that the treatments did not differ statistically after the one-way ANOVA followed by the Tukey post-hoc test (p $<0.05$ ).

Table 3. Coefficients of variation of the mechanical properties of the particleboards.

\begin{tabular}{|c|c|c|c|c|}
\hline \multirow{2}{*}{ Treatments } & \multicolumn{4}{|c|}{ Coefficient of variation (\%) } \\
\hline & MOR (MPa) & MOE (MPa) & IB (MPa) & $\mathbf{S P}(\mathbf{N})$ \\
\hline MM90 & $5.54 \%$ & $8.93 \%$ & $8.56 \%$ & $4.00 \%$ \\
\hline MM110 & $10.26 \%$ & $9.13 \%$ & $20.26 \%$ & $39.00 \%$ \\
\hline MM130 & $10.17 \%$ & $13.09 \%$ & $14.16 \%$ & $2.12 \%$ \\
\hline
\end{tabular}

\subsection{Mechanical characterization of the particleboards}

Tables 2 and 3 list the results of the mechanical tests of static bending strength (MOR and MOE), perpendicular tensile strength (IB) and screw pullout (SP) and their respective coefficients of variation. Table 2 indicates that the MOR increased with increasing processing temperature. At $130^{\circ} \mathrm{C}$, the average MOR (19.57 MPa) was similar to that obtained by Iwakiri et al. ${ }^{32}$ and exceeded the value recommended by the NBR 14810-2 standard $^{43}$, showing a statistically significant difference from the first two MOR values. However, these values are higher than the $13 \mathrm{MPa}$ recommended by the EN 312:2010 standard ${ }^{47}$. The results indicate that particleboards processed at $130^{\circ} \mathrm{C}$ using twocomponent castor oil based resin and Tauari wood particles have a promising potential to be classified as high density particleboards indicated for commercial and industrial applications ${ }^{28}$.

The mean values of modulus of elasticity (MOE) of the particleboards (Table 2) did not reach the minimum value (2750 MPa) recommended by the A208-1-1999 standard $^{44}$ in any of the treatments, and the MOE value obtained at $130^{\circ} \mathrm{C}$ (2378.5 MPa) was $15.62 \%$ lower than that recommended by the aforementioned standard; however, all the values exceeded those recommended by the EN 312:2010 standard. Several researchers have reported low MOE values ${ }^{16,26,30,41}$, attributing this behavior to poor distribution of the adhesive during the compression of particleboards. The static bending tests showed statistical differences between the modulus of rupture (MOR) and of elasticity (MOE) as a function of the temperature.

As for thickness swelling, the IB test results shown in Table 2 demonstrate that, regardless of the processing temperature, the mean values of this property varied from 1.55 to $1.70 \mathrm{MPa}$, which are higher than those recommended by the NBR 14810-2, A208.1:1999, and EN 312:2010 standards $^{43,44,47}$. The mean values of IB showed no statistically significant differences at a $5 \%$ level of probability and are in agreement with those reported by Iwakiri et al. ${ }^{32}$ for Tauri wood.

The mean screw pullout (SP) values of the particleboards produced in this study at all the temperatures were higher than the minimum of $1020 \mathrm{~N}$ at the surface and $800 \mathrm{~N}$ at the top, established by the NBR 14810-2 standard. The treatments at 90 and $110^{\circ} \mathrm{C}$ showed no statistically significant differences at the $5 \%$ level.

It is important to note that the coefficients of variation of the properties of MOR, MOE and IB were below the recommended $20 \%$, and these values ensure the consistency of the manufacturing process.

\section{Conclusions}

Tauari wood particleboards agglomerated with bicomponent castor oil based polyurethane resin, with an average density ranging from 930 to $940 \mathrm{~kg} \cdot \mathrm{m}^{-3}$, can be produced in the laboratory with physical and mechanical properties suitable for commercial and industrial applications.

The compaction pressure of $5 \mathrm{MPa}$ and a compaction ratio above 1.5 were suitable for the compression of Tauari particleboards with densities exceeding $900 \mathrm{~kg} \cdot \mathrm{m}^{-3}$ and a thickness of $10 \mathrm{~mm}$, at all the processing temperatures.

The use of $16 \%$ (based on wood mass) of bi-component castor oil-based polyurethane resin results in IB values exceeding those recommended by the Brazilian NBR 14810-2 standard.

The particleboards compressed at $130^{\circ} \mathrm{C}$ showed better physical and mechanical properties than those compressed at 90 and $110^{\circ} \mathrm{C}$, indicating that this is the best compression temperature.

Regardless of the processing temperature, the particleboards showed higher values of tensile strength perpendicular to fibers (internal bonding) and screw pullout than those required by the Brazilian and American standards.

\section{Acknowledgements}

The authors thank the Wood and Timber Structures Laboratory of the University of São Paulo at São Carlos (LaMEM/USP), which enabled the production of the particleboards, and FAPEMA (Maranhão Foundation for Scientific Research and Development) for its financial support. 


\section{References}

1. Amaral P and Amaral NM. Manejo florestal comunitário: processos e aprendizagens na Amazônia brasileira e na América Latina. Belém: IEB; IMAZON; 2005. 44 p.

2. Monteiro ALS, Souza CM Jr, Barreto PG, Pantoja FLS and Gerwing JJ. Impactos da Exploração Madeireira e do Fogo em Florestas de Transição da Amazônia Legal. Scientia Forestalis. 2004; 65:11-21.

3. Oliveira LC, Valentim NW, Figueiredo EO and Franke IL. Impactos da Exploração Seletiva de Madeira em Áreas em Processo de Fragmentação Florestal na Amazônia Ocidental. Cerne. 2003; 9(2):213-220.

4. Chamma PVC and Leão AL. Aproveitamento de resíduos sólidos na produção de painéis para aplicações arquitetônicas. Revista Energia na Agricultura. 2008; 23(2):73-84.

5. Silva AJP. Aplicação de partículas longas e orientadas de bagaço de cana de açúcar na produção de painel particulado similar ao OSB. [Tese]. São Carlos: Universidade de São Paulo; 2006. 144 p.

6. Silva SAM and Lahr FAR. Chapas de partículas Confeccionadas com Resíduos de madeiras tropicais de baixa e média densidade. Reciclagem de resíduos para a construção civil. Belo Horizonte. FUMEC-FEA; 2007. p. 01, p. 343-365.

7. Poleto SFS, Bertolini MS, Nascimento MF and Rocco Lahr FA. Produção de Chapas de Partículas homogêneas (CPH) utilizando resíduos de espécies de reflorestamento. Reciclagem de resíduos para a construção civil. Belo Horizonte: FUMECFEA; 2007. v. 01, p. 271-292.

8. Carvalho RS and Oliveira AD. Viabilidade Econômica do Manejo Florestal Madeireiro em Projetos de Assentamento Extrativistas no Sudoeste da Amazônia. Cerne. 2010; 16(4):505-516.

9. Brito EO. Estimativa da produção de resíduos da Indústria brasileira de serraria e laminação de madeira. Revista da Madeira. 1995; 4(26):34-39.

10. Vasconcelos FJ, Freitas JA, Lima VMOC, Monteiro LV and Pereira SJ. Madeiras tropicais de uso industrial do Maranhão: Características tecnológicas. Manaus: INPA, Coordenação de Pesquisas em Produtos Florestais, UFMA, Centro Tecnológico; 2001. $96 \mathrm{p}$.

11. Manieri C. Fichas Características das Madeiras Brasileiras. 2. ed. São Paulo: IPI; 1980. 418 p.

12. Maloney TM. Modern particleboard \& dry-process fiberboard manufacturing. San Francisco: Miller Freeman; 1977. 681 p.

13. Leão AL, Tan IH and Craschi JC. Curaua fiber - A tropical natural fibers from Amazon - Potential and Application in Composites. In: Proceedings of the International Conference on Advanced Composites; 1998. p. 557-564.

14. Iwakiri S, Silva JC, Silva, Alves CR and Puehringer CA. Produção de compensados de Pinus taeda L.E e Pinus oocarpa Schiede com diferentes formulações de adesivo ureia formaldeído. Revista Árvore. 2002; 26(3):371-375. http:// dx.doi.org/10.1590/S0100-67622002000300013

15. Carneiro ACO, Vital BR, Frederico PGU, Santos RC and Sousa WP Jr. Propriedades de chapas de flocos fabricadas com adesivo de uréia-formaldeído e de taninos da casca de Eucalyptus grandis W. Hill ex Maiden ou de Eucalyptus pellita F. Muell. Revista Árvore. 2004: 28(5):715-724. http://dx.doi. org/10.1590/S0100-67622004000500011

16. Iwakiri S, Shimizu J, Silva JC, Del Menezzi CHS, Puehringer $\mathrm{CA}$, Venson I et al. Produção de painéis de madeira aglomerada de Grevillea robusta A. Cunn. ex R. Br.. Revista Árvore.
2004; 28(6):883-887. http://dx.doi.org/10.1590/S010067622004000600013

17. Bonelli CMC, Elzubair A, Miguez Suarez JC and Mano EB. Comportamento térmico, mecânico e morfológico de compósitos de polietileno de alta densidade reciclado com fibra de piaçava. Polímeros. 2005; 15(4):256-260. http://dx.doi. org/10.1590/S0104-14282005000400009

18. Fonseca FMC. Desenvolvimento e Caracterização de Compósitos à base Polietileno de Alta Densidade (PEAD) Reciclado com Fibras Vegetais. [Dissertação]. Belo Horizonte: Universidade Federal de Ouro Preto; 2005. p.133.

19. Que Z, Furunoa T, Katoha S and Nishino Y. Effects of urea-formaldehyde resin mole ratio on the properties of particleboard.. Effects of urea-formaldehyde resin mole ratio on the properties of particleboard. Building and Environment. 2007; 42(3):1257-1263. http://dx.doi. org/10.1016/j.buildenv.2005.11.028

20. Buyuksari U, Ayrilmis N, Avci E and Koc E. Evaluation of the physical, mechanical properties and formaldehyde emission of particleboard manufactured from waste stone pine Pinus pinea L. cones. Bioresource Technology. 2010; 101(01):255-259. http://dx.doi.org/10.1016/j.biortech.2009.08.038

21. Iwakiri S, Caprara AC, Saks DCO, Guisantes FP, Franzoni JÁ, Krambeck LBP et al. Produção de painéis de madeira aglomerada de alta densificação com diferentes tipos de resinas. Produção de painéis de madeira aglomerada de alta densificação com diferentes tipos de resinas. Scientia Forestalis. 2005; 68:39-43.

22. Araújo LCR. Caracterização Química, Térmica e Mecânica de Poliuretanas Elastoméricas Baseadas em Materiais Oleoquímicos. [Dissertação]. São Paulo: Universidade de São Paulo; 1992.

23. König B Jr, Forger S F, Mascaro MB and Beck TJ. Biocompatibility of the polyurethane resin of the castor bean inserted into the alveolar bone of the dog. Annals of Anatomy. 1999; 181(6):582-584.

24. Claro SN. Caracterizações físico-químicas de um poliuretano derivado de óleo de mamona utilizado para implantes ósseos. [Tese]. São Carlos: Instituto de Química de São Carlos, Universidade de São Paulo; 1997. 127 p.

25. Ogunniyi DS. Castor oil: A vital industrial raw material. Review Paper. Bioresource Technology. 2005; 97(9):1086-1091. http:// dx.doi.org/10.1016/j.biortech.2005.03.028

26. Dias FM and Rocco Lahr FA. Fabricación de Madera Contraplacada con Adhesivo Poliuretano Alternativo a Base de Rícino. Maderas. Ciencia y tecnología. 2003; 5(2):163-175.

27. Campos CI and Rocco Lahr FA. Production and Characterization of MDF Using Eucalyptus Fibers and Castor Oil-based Polyurethane Resin. Materials Research. 2004; 7(3):421-425. http://dx.doi.org/10.1590/S1516-14392004000300008

28. Iwakiri S, Mercadante Stinghen AB, Da Silveira EL, Cavalli Zamarian EH, Prata JG and Bronoski M. Influência da Massa Específica Sobre as Propriedades Mecânicas de Painéis Aglomerados. Floresta. 2008; 38(3):487-493.

29. Fiorelli J, Rocco Lahr FA, Nascimento MF Savastano H Jr and Rossignolo JA. Painéis de partículas à base de bagaço de cana e resina de mamona - produção e propriedades. Acta Scientiarum Technology. 2011; 33(4):401-406. http://dx.doi. org/10.4025/actascitechnol.v33i4.9615

30. Paes JB, Nunes ST, Rocco Lahr FA, Nascimento MF and Lacerda RMA. Qualidade de chapas de partículas de pinus elliottii coladas com resina poliuretana sob diferentes combinações de pressão e temperatura. Ciência Florestal. 2011; 21(3):551-558. 
31. Fiorelli J, Donizetti Curtolo D, Barrero NG, Savastano H Jr, Agnolon Pallone EMJ and Johnson R. Particulate composite based on coconut fiber and castor oil polyurethane adhesive: An eco-efficient product. Industrial Crops and Products. 2012; 40:69-75. http://dx.doi.org/10.1016/j.indcrop.2012.02.033

32. Iwakiri S, Vianez BF, Weber C, Trianoski R and Almeida VC. Avaliação das propriedades de painéis aglomerados produzidos com resíduos de serrarias de nove espécies de madeiras tropicais da Amazônia. Acta Amazônica. 2012; 42(1):59-64. http://dx.doi.org/10.1590/S0044-59672012000100007

33. Bertolini MS, Nascimento MF, Blecha KA and Rocco Lahr FA. Eco-panels Based on Wastes from Urban Trees and Castor Oil Polyurethane Resin. International Journal of Agriculture and Forestry. 2013; 3(1):12-15.

34. Silva RV, Spinelli D, Bose WW F $\mathrm{F}^{\circ}$, Claro $\mathrm{S} \mathrm{N}^{\circ}$, Chierice GO and Tarpani JR. Fracture toughness of natural fibers/ castor oil polyurethane composites. Composites Science and Technology. 2006; 66:1328-1335. http://dx.doi.org/10.1016/j. compscitech.2005.10.012

35. Silva SAM, Christoforo AL, Ribeiro SLM F ${ }^{\circ}$, Varanda LD and Rocco Lahr FA. Particleboard Manufactured with Bi-component Polyurethane Resin Base on Castor Oil. International Journal of Composite Materials. 2012; 2(6):115118. http://dx.doi.org/10.5923/j.cmaterials.20120206.01

36. Silva SAM, Christoforo AL, Panzera TH, Almeida DH, Da Silva Segantini AA and Rocco Lahr FA. Painéis de partículas de madeira leucena e resina poliuretana derivada de óleo de mamona. Ciência Rural. 2013; 43(8):1399-1404. http://dx.doi. org/10.1590/S0103-84782013005000099

37. Associação Brasileira de Normas Técnicas - ABNT. NBR 14810-3: Chapas de madeira aglomerada. Parte 3: Métodos de ensaio. Rio de Janeiro; 2006.

38. Sartori DL, Cravo JCM, Barrero NG, Fiorelli J and Savastano H Jr. Painel em Madeira de Reflorestamento e Chapas de
Partículas para Instalações Rurais. Floresta e Ambiente. 2012; 19(2):171-178. http://dx.doi.org/10.4322/floram.2012.020

39. Moslemi AA. Particleboard: Materials. Illinois: Southern Illinois University Press; 1974. v. 1, 245 p.

40. American National Standards Institute - ANSI. ANSI A208.1: Particleboard: specification. Gaithersburg; 1999.

41. Contreras WM, Owen MEC, Cloquell VB, Contreras YM and Garay DAJ. Diseño de tableros de partículas de caña brava y adhesivo fenol - formaldehído. Revista Forestal Latinoamericana. 2006: 21(39):39-55.

42. Moreno PA, Garay DA, Durán JA and Valero SW.. Utilización de bambusa vulgaris como una alternativa en la fabricación de tableros aglomerados de partículas. Revista Forestal Latinoamericana. 2007; 22(42):31-50.

43. Associação Brasileira de Normas Técnicas - ABNT. NBR 14810-2: Chapas de madeira aglomerada. Parte 2: Requisitos. Rio de Janeiro; 2006.

44. Riegel IC, Moura ABD, Morisso FDP and Mello FSI. Análise Termogravimétrica da Pirólise da Acácia-Negra (Acácia mearnsii) Cultivada no Rio Grande do Sul, Brasil. Revista Árvore. 2008; 32(3):533-543. http://dx.doi.org/10.1590/S010067622008000300014

45. Fiorelli J, Sartoria DL, Machado Cravo JC, Savastano H Jr, Rossignolo JA, Nascimento MF et al. Sugarcane Bagasse and Castor Oil Polyurethane Adhesive-based Particulate Composite. Materials Research. 2016; 16(2):439-446. http:// dx.doi.org/10.1590/S1516-14392013005000004

46. Bertolini MS, Rocco Lahr FA, Nascimento MF and Marcondes Agnelli JA. Accelerated Artificial Aging of Particleboards from Residues of CCB Treated Pinus sp. and Castor Oil Resin. Materials Research. 2013; 16(2):293-303. http://dx.doi. org/10.1590/S1516-14392013005000003

47. European Committee for Standardization. Norma EN 312. Particleboard - Specifications. Bruxelas; 2010. 